http://jmscr.igmpublication.org/home/

ISSN (e)-2347-176x ISSN (p) 2455-0450

crossref DOI: https://dx.doi.org/10.18535/jmscr/v8i7.63

Journal Of Medical Science And Clinical Research

\title{
Early prenatal diagnosis of Ischiopagus conjoint twins at 12 weeks of gestation
}

\author{
Authors \\ Sapna Berry ${ }^{1}{\text { Naveen } \text { Kumar }^{2 *}}^{*}$ \\ ${ }^{1}$ Post graduate in Department of Obstetrics and Gynecology IGMC Shimla HP India \\ ${ }^{2}$ Post graduate in Department of Paediatrics IGMC Shimla HP India \\ *Corresponding Author
}

Dr Naveen Kumar

\begin{abstract}
Conjoint twins (CTs) are a very rare entity since it is estimated to occur in 1.5 per 100,000 births worldwide. Female:male CTs are 3:1. Conjoint twins are monozygotic twins. In this sense, they share the same zygote where the twinning is initiated after 13 days of fertilization of egg. Ischiopagus is a very rare variety of conjoined twins with very few cases reported in the literature. Ultrasonography has made early diagnosis of conjoined twins possible, allowing prompt management and counselling of parents. The location and extent of fusion between the twins determine the potential for surgical separation and postnatal survival. Here a case of conjoined ischiophagus twins, diagnosed by ultrasonography at 12 weeks of gestation is presented. Due to high complexity of fetal fusion, termination of pregnancy was performed upon patient's request.

Keywords: Conjoined twins, Prenatal diagnosis, ischiopagus, Ultrasonography.
\end{abstract}

\section{Introduction}

Conjoined twins represent one of the rarest forms of twin gestation, estimated to occur in 1.5 per 100,000 births worldwide. In about $1 \%$ of monochorionic pregnancies, the twins are conjoined, probably resulting from relatively late attempts at cleavage on day 13 or later. ${ }^{1-5}$ Therefore, when there is a case of monochorionic monoamniotic pregnancy, the possibility of conjoined twins should always be kept in mind. Ultrasonography plays the most important role in the diagnosis. Prenatal ultrasound diagnosis has been described since 1974, and nowadays most of the cases are diagnosed early in pregnancy. ${ }^{6}$ The most common types of conjoined twins are thoracopagus, omphalopagus and thoracoomphalopagus. ${ }^{7}$ Only about $12 \%$ are of the ischiopagus variety ${ }^{8}$, which refer to twins joined at the level of the ischium. Ischiopagus twins are joined at the pelvis and they usually have three (tripus) or four (tetrapus) limbs. About half of the ischiopagus have four separate lower limbs, 1/3rd have 3 lower limbs (2 separate and 1 fused) attached to the body laterally and $1 / 5$ th cases are parasitic. ${ }^{9} \mathrm{We}$ present here a case of ischiopagus tetrapus conjoint twins which were diagnosed at 12 weeks of gestation. 


\section{Case report}

A 27-year-old woman, gravida 2 para 1, was referred to our hospital at 12 weeks of gestation for suspected conjoined twins after a routine ultrasound examination. Her past medical history was unremarkable, there was no family history of twins and the actual pregnancy was a spontaneous conception. Present ultrasound (US) revealed a monochorionic monoamniotic twin pregnancy with two fetuses in a fixed face-to-face position. Two-dimensional (2D) ultrasonography revealed monoamniotic twins lying face-to-face, one yolk sac (Figure 1) and two separate cardiac pulsations. The embryos were fused at the lower part of the trunk and were suspected to be twins ischiopagus conjoined at the level of the pelvis. There was no change in the relative positions of the fetuses despite attempts. Subsequently, a threedimensional (3D) volume dataset of the embryos was acquired using transvaginal ultrasonography with power Doppler. Vascular communication between the conjoined twins in the pubic area was accurately delineated (Figure 2).On the base of these findings, the diagnosis of conjoint twins was made. The couple was informed about ultrasound findings and counselled on the management options. They opted for termination of pregnancy, which was performed medically within one week. After evacuation, two separate bodies and two separate upper and lower extremities were noted. The two babies were joined at the pelvic and perineal regions with the vertebral axis at $180^{\circ}$ with each other. Each twin had its own pair of lower limbs oriented at right angles to the axis of the common trunk. External genitalia was absent for both twins. No separate urethral opening was present. (Figure 3)

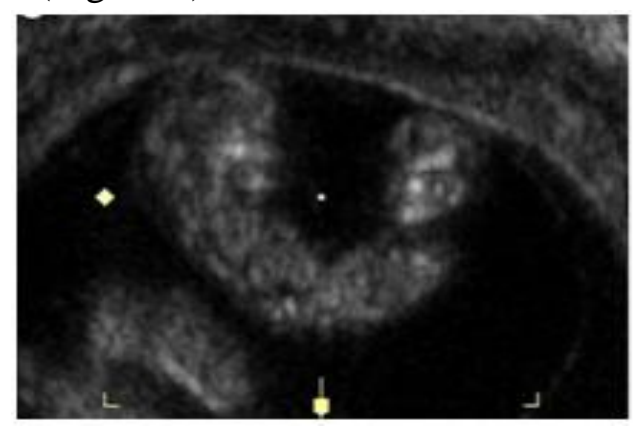

Figure 1

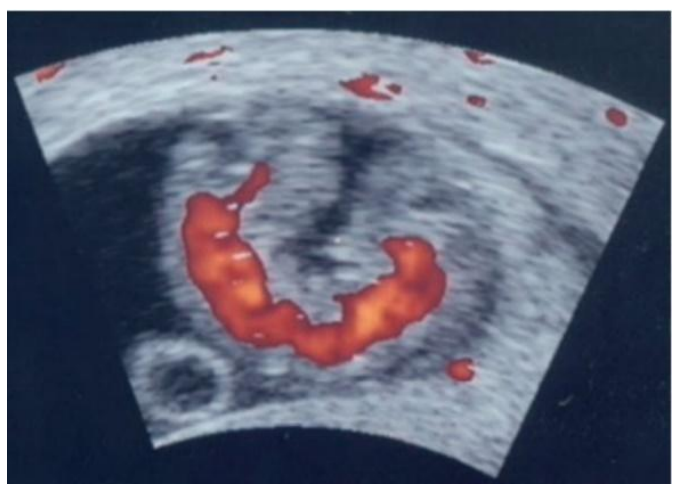

Figure 2

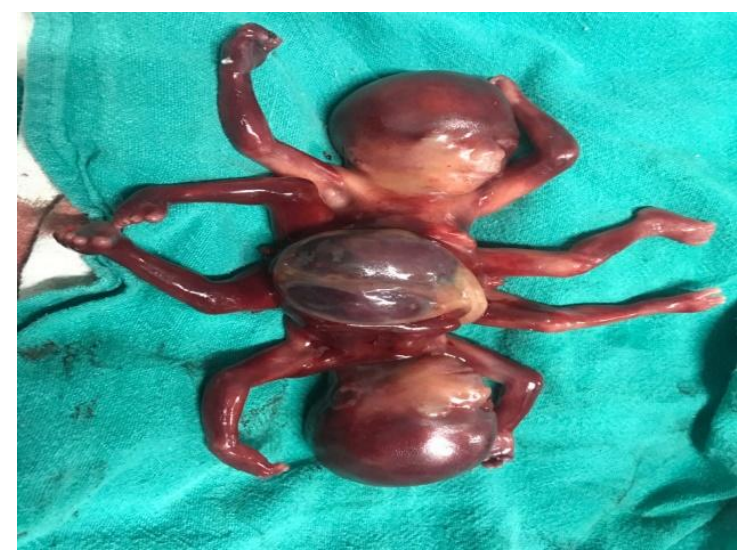

Figure 3

\section{Discussion}

Conjoined twins are a rare type of monochorionic twins, estimated to occur in 1.5 per 100.000 births worldwide. ${ }^{1-4}$ Etiology is unknown, but there are two different theories that explain the formation of conjoined twins. According to the fission theory, 13-15 days after fertilization, the embryonic disc undergoes an incomplete separation, whereas in the "fusion theory" two separate monoovulatory embryonic discs undergo a secondary association. ${ }^{1,4}$ Female fetuses are more commonly affected with male to female ratio of $1: 3$, particularly in thoracopagus type. ${ }^{5,6}$ Based on the anatomical site of union, conjoined twins are classified as craniopagus (skull), thoracopagus (thorax), omphalopagus (abdomen) ischiopagus (ischia), rachipagus (vertebral column), pygopagus (sacrum) and parapagus (torso). The most frequent type of all conjoined twins is thoracopagus $(40 \%)$ and the rarest is craniopagus. ${ }^{10}$ Grossly, ischiopagus usually lie along a long axis with heads on opposite sides. They have a common umbilicus and the bodies 
fuse below this level, sharing lower abdomen and pelvis. About half of the ischiopagus have four separate lower limbs, one-third have three lower limbs (two separate and one fused) attached to the body laterally and one fifth of the cases are parasitic. Our case, therefore, is an example of ischiopagus tetrapus. Turner et al remarked magnetic resonance imaging is superior to computed tomography, due to the lack of exposure to radiation during antenatal period. ${ }^{\mathbf{1 1}}$

Early diagnosis by US is possible in modern day obstetrics. Suspicious US findings that may suggest the diagnosis include: both fetal heads in the same plane, no change in the relative position after maternal movement and manual manipulation, contiguous skin, unusual limb position and more than three vessels in the cord. ${ }^{3}$

Surgery to separate conjoined twins may range from relatively simple to extremely complex, depending on the points of fusion and the shared organs. Most cases of separation are extremely risky and life-threatening. ${ }^{1}$ Prognosis is very poor among conjoined twins in general. In all, 40-60\% are stillbirths and among the live births, almost $35 \%$ do not survive beyond 24 hours of life. The present case focuses on morphological features of an early diagnosis of ischiopagus conjoined twins, emphasizing the importance of sonographic assessment in all twin pregnancies. ${ }^{12}$

\section{References}

1. Osmanagaoglu MA, Aran T, Guven S, Kart C, Ozdemir O, Bozkaya H. Thoracopagus conjoined twins: a case report. ISRN Obstet Gynecol. 2011; 2011:3.

2. Herkiloglu D, Baksu B, Pekin O. Early prenantal diagnosis of thoracoomphalopagus twins at ten weeks of gestation by ultrasound. Turk J Obstet Gynecol. 2016;13:106-8.

3. Alkhateeb M, Mashaqbeh M, Magableh S, Rafiq H, Quteiba N, Abdelkheleg A. Early Prenatal Diagnosis of thoracopagus twins by ultrasound. Acta Informed Med. 2015;23:60-2.

4. Oksuzoglu A, Moraloglu O, Aktulay A, Yaprak E, Sevki C, Leyla M. Conjoined Twins: a case report of thoracoomphalopagus. J Ank Univ Fac Med. 2011;64:3.

5. Mishra N, Rohilla M. Thoracoomphalopagus conjoined twins: a case report and literature review. Gynacol Obstet Case Report. 2015;1:3.

6. Brizot ML, Liao AW, Lopes LM, Okumura M, Marques MS, Krebs V, et al. Conjoined twins pregnancies: experience with 36 cases from a single center. Prenat Diagn. 2011;31:1120-5.

7. Edmonds LD, Layde PM. Conjoined twins in the United States, 1970-1977. Teratology 1982; 25: 301-08.

8. Verrier MD, Hastings CJ, Hoffman EB. Posterior iliac osteotomy in ischiopagus tetrapus twins. J Pediat rOrthop 2000; 20: 807-811.

9. O’Neil JA, Holcomb GW III, Schnaufer L, Templeton JM, Bishop HC, Ross AJ III (1988) Surgical experience with thirteen conjoined twins. Ann Surg, 208: 299-310.

10. Krawczyk J, Borowsky D, Wegrzyn P, Drews K. Siamese twins-prenatal diagnosis in the first trimestre of pregnancy. Case study and review. Ginekol Pol. 2015:86:477-9.

11. Garg R, Agrawal R, Singh S, Agrawal M. Ischiopagus Conjoined Twins delivered Vaginally. World J Anemia 2018;2(1):3133.

12. Cunha SS, Coutada RS, Neiva AR, Nogueira R. Early prenatal diagnosis of conjoined twins: a case report. Int J Reprod Contracept Obstet Gynecol 2018;7:5162-4. 